Agrotrópica 27(3): 215 - 218. 2015.

Centro de Pesquisas do Cacau, Ilhéus, Bahia, Brasil

\title{
GENETIC PARAMETERS AND RESISTANCE OF CACAO PROGENIES TO CERATOCYSTIS WILT UNDER NATURAL INFECTION
}

\author{
Milton Macoto Yamada', Fábio Gelape Faleiro², Uilson Vanderlei Lopes ${ }^{1}$, José Luis Pires ${ }^{1}$ \\ ${ }^{1}$ CEPLAC/CEPEC, km 22 rod Ilhéus-Itabuna, Caixa postal 7, 45600-970, Itabuna, Bahia, Brasil. macoto@ cepec.gov.br. \\ ${ }^{2}$ Centro de Pesquisa Agropecuária dos Cerrados, BR 020, km 18, Caixa postal 08223, EMBRAPA, 73301-970, Planaltina, \\ DF, Brasil.
}

The objective of this study was to evaluate the resistance to the fungus Ceratocystis cacaofunesta, causing Ceratocystis wilt, a lethal disease of cacao. In March 2005, in the Joaquim Bahiana Experimental Station (ESJOB) of the Cocoa Research Center (Cepec) located in the municipality of Itajuípe, Bahia, Brazil was an experiment installed in the field with progenies of 27 crosses arranged in randomized blocks with spacing of $3 \times 3$ meters with plots of 30 plants and four repetitions, with a total of 120 plants /crosses. The plants of progenies from 27 crosses were evaluated in relation to disease, and, in October 2012, data of the incidence of dead plants were subjected to analysis of variance and heritability. The mean disease incidence ranged from 0.83 to $51.66 \%$, while the overall mean was $16.19 \%$ of dead plants. Progenies showed significant differences in incidence and resistance to Ceratocystis wilt. Natural selection performed in this experiment for resistance to Ceratocystis cacaofunesta was efficient considering the high heritability $(\mathrm{h} 2=0.92)$ and the value of the relationship $\mathrm{CVg} / \mathrm{CVe}=1.71$.

Key words: Theobroma cacao L., Ceratocystis wilt, natural selection, variance, heritability.

Parâmetros genéticos e resistência das progênies de cacaueiro à murcha de
ceratocystis em condições naturais. O objetivo deste trabalho foi avaliar a resistência do fungo Ceratocystis cacaofunesta, que causa a murcha de ceratocystis, doença letal do cacaueiro. Em março de 2005, na Estação Experimental Joaquim Bahiana do Centro de Pesquisas do Cacau (Cepec), situada no município de Itajuípe, Bahia, Brasil foi instalado no campo um experimento com progênies de 27 cruzamentos dispostos em blocos ao acaso no espaçamento de 3x3 metros com parcelas de 30 plantas e 4 repetições, totalizando 120 plantas/cruzamento. As plantas das progênies dos 27 cruzamentos foram avaliadas em relação à doença, e, em outubro de 2012 , os dados da incidência de plantas mortas foram submetidos à análise de variância e da herdabilidade. As médias de incidência da doença variaram de 0,83 a 51,66\%, enquanto que a média geral do experimento foi 16,19\% de plantas mortas. As progênies mostraram diferenças significativas de resistência e incidência à murcha de ceratocystis. A seleção natural realizada nas condições deste experimento para resistência a Ceratocystis cacaofunesta foi eficiente, considerando a alta herdabilidade $(\mathrm{h} 2=0,92)$ e o valor da relação $\mathrm{CVg} / \mathrm{CVe}=1,71$.

Palavras-chave: Theobroma cacao L., murcha de ceratocystis, seleção natural, variância, herdabilidade. 


\section{Introduction}

High economical and social impacts have happened in Bahia, since 1989, with the introduction of cacao (Theobroma cacao L.) witches' broom disease (Moniliophthora perniciosa) in the main producer region. Since then, considerable effort has been dedicated by breeders and pathologists aiming to obtain resistant varieties to the disease, and whith productivity and other desirable agronomic traits. However, a new disease Ceratocystis wilt, caused by the fungus Ceratocystis cacaofunesta sp. nov. (Engelbrecht and Harrington, 2005), was detected in the Bahian cacao region (Bezerra et al., 1998) and, lately, in the Espírito Santo State (Almeida et al., 2005). Since then it has caused significant yield losses. The disease is lethal to the cacao tree.

In countries where the disease occurs, several clones tested were resistant to the pathogen, as in Ecuador with IMC 67, Pound 12, SPA 9 (Delgado and Echandi, 1965; Soria and Salazar, 1965) and Pa 121 (Soria and Salazar, 1965). In Colombia, the clones ICS 6, TSA 654 (IMC $67 \times$ SCA 6) and ICS 95 were the ones that presented a high resistance level (Barros, 1981), while in Trinidad, the clones IMC 67, P 18 and TSA 654 were found resistant to the disease (Gonsalves, 1996). Among the most susceptible cultivars in the field include some high yielder clones as Sca 6, ICS 1, ICS 39, ICS 89, UF 654, UF 667 and UF 668 (Soria and Salazar, 1965).

In studies at the Cacao Research Center (CEPEC), inoculations in greenhouse using open pollinated progenies, some were found to be resistant to the disease, among them: FCB 01, CSG 70, BOBA01, VB 802, TSH 1188,VB 1151, PS 13.19 and MAC 01; while HW 25, PM 02, PH 15, MO 5 and BJ 11 moderately susceptible and CCN 51, FB 206, PH 16, SJ 02, CCN 10 and FSU 77 ; as susceptible (Silva et al., 2012). In another study, the clones FB 04, SCA 6, IPIR 1, PAT 301, RVID 08, SALOB 3, PH 92, FB 17, LP 24,TSH 1188 and VB 1151 were classified as resistant, and the clones EET 399, CCN 51 and SJ 02 as susceptible (Silva et al., 2010) using open pollinated progenies.

The segregation in ICS 1 x SCA 6 progenies, allowed the classification of 1 resistant, 9 moderately resistant and 54 susceptible (Soria and Salazar, 1965). Those data could indicate the complementary action of genes.
However, Gonsalves (1996) found in progenies of SCA $6 \times$ ICS 1 all the plants as being susceptible to Ceratocystis wilt . Based on mortality of plants in the field, in diallel cross, Gardella et al. (1982), found $38.06 \%$ of addictive effects for resistance, $31.42 \%$ of dominance effect and $30.52 \%$ of environmental effect, and, the clones IMC 67 and SPA9, as having dominant genes for resistance.

The selection of resistant genotypes to Ceratocystis wilt is the most economical and effective way of controlling the disease. This has led researchers at the Cacao Research Center (CEPEC), in Ilhéus, Bahia, to establish several resistance trials aiming the development of resistant varieties to farmers. The present work evaluated progenies of 27 cacao crosses, under field conditions, at CEPEC's Experimental Station Joaquim Bahiana, in Itajuípe, Bahia, Brazil.

\section{Materials and Methods}

The experiment was carried out at the Experimental Station “Joaquim Bahiana”(ESJOB), in Itajuípe, Bahia, Brazil, aiming the selection of plants with good agronomic traits, including resistance to the diseases for further testing as clones'regional trials, before the recommendation to farmers. The evaluation of dead plants in the field were accomplished in the progenies of 27 crosses (Table 2), using a randomized complete block design with plots of 30 plants and 4 replications with a total of 120 plants /cross. Plants were planted in the field in a 3 x 3 meters spacing, in March 2005, using Erythrina as shade tree. Before the establishment of the trial, it was detected a high mortality of trees on the susceptible progeny Sca 6 x ICS 1 (var. Theobahia) present in the area. Those trees constituted a source of inoculum of the pathogen to the trial used in this study. The incidence of the disease was evaluated as the percentage of dead plants in each plot of 30 plants in October 2012.

An analysis of variance of the data was performed and the averages compared by the Tukey test at $1 \%$ of significance, using Genes package (Cruz, 2006). The estimates of the genotypic ( $\hat{\sigma}_{\mathrm{g}}^{2}$ ), phenotypic at the average level $\left(\hat{\sigma}_{\mathrm{f}}^{2}\right)$ and environmental average $\left(\hat{\sigma}_{\mathrm{e}}^{2}\right)$ variances were estimated using the software Genes (Cruz, 2006). The same software was used also to estimate the heritability at the average level $\left(h^{2}\right)$, 
coefficients of experimental variation $(\mathrm{CVe})$, genetic $(\mathrm{CVg})$ and ratio $\mathrm{CVg} / \mathrm{CVe}$. These parameters were estimated as:

$$
\begin{aligned}
& \text { Phenotypic variance among } \\
& \text { the averages of the treatment } \hat{\sigma}_{f}^{2}=\frac{\mathrm{QMg}}{\mathrm{r}} \\
& \text { Environmental variance } \hat{\sigma}_{f}^{2}=\frac{\mathrm{QMg}}{\mathrm{r}} \\
& \text { Genotypic variance } \hat{\sigma}_{g}^{2}=\frac{\mathrm{QMg}-\mathrm{QMe}}{\mathrm{r}} \\
& \text { Heritability at the average level } h_{a}^{2}(\%)=\frac{\hat{\sigma}_{\mathrm{g}}^{2}}{\frac{\mathrm{QMg}}{\mathrm{r}}} 100 \\
& \text { Coefficient of experimental } \mathrm{CVe}(\%)=\frac{\sqrt{\mathrm{QMe}}}{\overline{\mathrm{x}}} 100, \\
& \text { variation }
\end{aligned}
$$

Where $\overline{\mathrm{x}}=$ average of the incidence of the disease.

Coefficient of genetic variation $\operatorname{CVg}(\%)=\frac{\sqrt{\hat{\sigma}_{g}^{2}}}{\bar{x}} 100$

$$
\text { Ratio } \mathrm{CVg} / \mathrm{CVe}=\sqrt{\frac{\hat{\sigma}_{\mathrm{g}}^{2}}{\hat{\sigma}^{2}}}
$$

\section{Results and Discussion}

Significant differences were observed by the test $\mathrm{F}$, at $1 \%$ of probability, among the cacao progenies for the incidence of the Ceratocystis wilt (Table 1). Besides that, highly significant differences among the progenies, high heritability estimates can be verified based on the family average, what shows the accuracy and reliability of the phenotype as estimate of the genotype. The high $\mathrm{CVg} / \mathrm{CVe}$ ratio (1.7), shows that selection based on disease incidence, under natural infection, can result in genetic gains in breeding programs for resistance. Silva et al. (2013) also found high clonal heritability ( $\mathrm{h} 2=0.81,0.78$ e 0.93 ) for three traits for inoculations in field conditions.

The comparison among the progeny averages allowed the differentiation of those progenies in different resistance levels (Table 2). The averages incidence of the disease (percentage of dead plants) ranged from 0.83 to $51.66 \%$ (Table 2), being the overall experiment average $16.19 \%$ of dead plants (Table 1).

The highest mortality rates were verified when one of the progenitors was $\mathrm{CCN} 10, \mathrm{CCN} 51, \mathrm{CC} 10$ or CEPEC 515 (Table 2). The clone CCN 51, used as
Table 1. Analysis of variance, estimates of genetic parameters of the percentage of dead plants evaluated in 27 cacao progenies.

\begin{tabular}{|c|c|c|}
\hline Progenies & ercentage of dead plants & Tukey test $* *$ \\
\hline SGU 26 x CCN 51 & 51.66 & $\mathrm{a}$ \\
\hline EET 45 x CC 10 & 36.66 & $a b$ \\
\hline CEPEC 515 x CC 10 & 30.83 & $\mathrm{bc}$ \\
\hline CEPEC 515 x SGU 54 & 29.16 & bcd \\
\hline CC 10 x CCN 10 & 28.33 & bcde \\
\hline RB 39 x CCN 51 & 25.83 & bcdef \\
\hline EET 392 x CCN 51 & 22.50 & bcdefg \\
\hline CEPEC 94 x CCN 10 & 20.83 & bcdefgh \\
\hline EET 62 x VB 514 & 18.88 & bcdefgh \\
\hline PA $300 \times$ CCN 10 & 18.33 & bcdefgh \\
\hline TSH 1188 x CC10 & 18.33 & bcdefgh \\
\hline TSH1 188 x CCN 10 & 17.50 & bcdefgh \\
\hline PA 169 x CCN 10 & 15.83 & cdefgh \\
\hline TSH 565 x VB 184 & 12.50 & cdefgh \\
\hline TSH 1188 x SGU 54 & 10.83 & cdefgh \\
\hline TSH 565 x VB 1139 & 10.00 & defgh \\
\hline PA 285 x TSH 565 & 9.16 & defgh \\
\hline VB 184 x SIC 19 & 9.16 & defgh \\
\hline CEPEC 523 x CCN 51 & 8.33 & efgh \\
\hline VB 184 x SGU 54 & 7.50 & fgh \\
\hline CEPEC 42 x SIC 19 & 7.50 & fgh \\
\hline TSH 565 x CSG 70 & 6.66 & fgh \\
\hline CCN 10 x VB 1151 & 6.66 & fgh \\
\hline CASA x CCN 10 & 5.83 & fgh \\
\hline TSH 1188 x CEPEC 515 & 5.00 & gh \\
\hline CEPEC 94 x AC 01 & 2.50 & gh \\
\hline TSH 1188 x VB 1151 & 0.83 & $\mathrm{~h}$ \\
\hline
\end{tabular}
Joaquim Bahiana Experimental Station (ESJOB), Itajuípe, Bahia, Brazil

\begin{tabular}{lrrr}
\hline Source of variation & \multicolumn{1}{c}{ df } & Mean Square & F Value \\
\hline Block & 3 & 32.88 & \\
Progenie & 26 & 555.35 & $12.67 * *$ \\
Error & 78 & 43.84 & \\
Total & $\mathbf{1 0 7}$ & & \\
\hline Mean & 16.19 & & \\
Phenotypic variance & 138.84 & & \\
Enviromental variance & 10.96 & & \\
Genotypic variance & 127.88 & & \\
\hline Heritability & 92.10 & & \\
CVg & 69.85 & & \\
CVe & 40.9 & & \\
CVg/CVe ratio & 1.71 & & \\
\hline
\end{tabular}

Table 2. Average of percentage of dead plants in 27 cocoa tree progenies evaluated in October of 2012. Joaquim Bahiana Experimental Station(ESJOB), Itajuípe, Bahia, Brazil 
susceptible control in other studies (Silva et al. 2010, 2012), as well as CCN 10, CC 10, CEPEC 515 should be susceptible (Table 2). However, the rate of mortality progenies of those clones decreased when they were crossed with resistant clones as in CEPEC $523 \mathrm{x}$ CCN51 (8.33\%), CCN $10 x$ VB 1151 (6. 66\%), CASA $x$ CCN $10(5.83 \%)$ and TSH 1188 x CEPEC 515 (5\%). The clones CEPEC 523, VB 1151, CASA and TSH 1188 are resistant. Clones VB 1151 and TSH 1188 have been used as resistant control in other studies (Silva et al., 2010, 2012) and in this experiment the crosses between the two, resulted in very low frequency of dead plants $(0.83 \%)$ (Table 2$)$.

The results of this work confirm the resistance of VB 1151, TSH 1188, CSG 70 and MAC 01 (used the acronym AC 01 in this work) found by Silva et al. (2012). When crosses involving resistant $\mathrm{x}$ resistant parents, as in TSH 1188 x VB $1151(0.83 \%)$ or susceptible $\mathrm{x}$ susceptible, as in SGU 26 x CCN 51 (51.66\%) and EET 45 x CC $10(36.66 \%)$ are considered, they occupy the extreme of dispersion in the averages of dead plants. A very high agreement was verified with the results of other works in spite of the differences in inoculation methods (natural field infections vs. greenhouse artificial inoculation) (Silva et al., 2010, 2012). Also, a significant correlation coeficient $(\mathrm{r}=.60 * *)$ has been observed between greenhouse and field incidence of Ceratocystis wilt previously (Yamada et al., 2012).

Many high yielder plants have been selected in this trial for further tests as clones in regional trials, particularly in the progenies of RB $39 \times$ CCN 51, CEPEC $94 \times$ CCN 10, PA 169 x CCN 10 and CCN 10 x VB 1151 (Yamada et al., 2013). However, as shown in this study these progenies a high number of dead plants, except in the cross CCN $10 \times$ VB 1151(Table 2). The natural selections for the resistance to that disease must have happened, that can be demonstrated in subsequent studies with those selected plants. Natural selection for resistance to Ceratocystis cacaofunesta must have been efficient in reason of the high heritability (Table 1) found in this experiment, and the occurrence of the dead plants in all replications, with a wide dispersion of the disease inside the experiment.

Considering the results of the present work, it could be recommended the cross TSH $1188 \times$ VB 1151 as rootstock (very low \% of dead plants). However, restriction should be made because under field conditions, this was the progeny with the highest production of vegetative and cushion brooms in the experiment (Yamada et al., 2013).

The natural selection for resistance to Ceratocystis cacaofunesta can be efficient considering the high heritability found and value of the ratio $\mathrm{CVg} / \mathrm{CVe}$ superior to the unit.

\section{Literature Cited}

ALMEIDA, L. C. C. et al. 2005. Distribuição geográfica da murchade-ceratocystis do cacaueiro na Bahia, Brasil. Agrotrópica (Brasil) 17:83-86.

BARROS, N. O. 1981. Cacao. Manual de assistência técnica, ${ }^{\circ}$ 23. Bogotá. Instituto Colombiano Agropecuário. 286p.

BEZERRA, J. L. et al. 1998. Ocorrência de Ceratocystis fimbriata em clones de cacau no estado da Bahia. Fitopatologia Brasileira 23: 228. (Resumo).

CRUZ C.D. 2006. Programa Genes. Estatística Experimental e Matrizes 1 ed. Viçosa, Editora UFV. 285p.

DELGADO, J. C.; ECHANDI, E. 1965. Evaluacion de la resistência de espécies y clones de cacao al mal del machete provocado por Ceratocystis fimbriata. Turrialba (Costa Rica) 15: 286-289.

ENGELBRECHT, C. J. B.; HARRINGTON, T. C. 2005. Intersterility, morphology and taxonomy of Ceratocystis fimbriata on sweet potato, cacao and sycamore. Mycologia 97(1): 57-69.

GARDELlA, D. S.; ENRIQUEZ, G. A.; SAUNDERS, J. L. 1982. Inheritance of clonal resistanceto Ceratocystis fimbriata in cacao hybrids. In: International Cocoa Research Conference, 8th. Proceedings. Cartagena, Colombia. Cocoa Producers'Alliance 695-702.

GONSALVES, C. 1996. History of cocoa breeding in the Ministry of Agriculture. Cocoa Research Units Newsletter, Trinidad 3:4-6.

SILVA, S. D. V. M. et al. 2010. Avaliação de clones de cacaueiros selecionados no sul da Bahia para resistência a Ceratocystis cacaofunesta. Agrotrópica (Brasil) 22 (3):165-170.

SILVA, S. D. V. M. et al. 2012. Resistência de progênies de cacaueiro à murcha-de-ceratocystis. Tropical Plant Pathology 37(3):191-195.

SILVA, S. D. V. M. et al. 2013. Seleção de clones de cacaueiros resistentes à murcha-de-Ceratocystis em condições de campo. Agrotrópica (Brasil) 25:163-170.

SORIA, V. J.; SALAZAR,G. 1965. Pruebas preliminaries de resistancia a Ceratocystis fimbriata em clones e hibridos de cacao. Turrialba (Costa Rica) 15 (4):290-295.

YAMADA, M. M. et al. 2012. Resistência de progênies de cacaueiro a murcha de-ceratocystis em condições de casa de vegetação e campo. In: International Cocoa Research Conference, 17th. Proceedings. Yaounde, Cameroon, Cocoa Producers Alliance. pp.1-6.

YAMADA, M. M. et al. 2013. Agronomic performance of 27 cocoa progenies and plant selections based on productivity, self compatibility and disease resistance. Revista Ceres (Brasil) 60(4):514-518. 